(including economic and political) studies, of theoretical students and practical men of affairs. The site is situated to the west of Oxford between Worcester College and Pembroke College. Two further bequests by Lord Nuffield include $£ 100,000$ for the erection and equipment of a new laboratory of physical chemistry and $£ 200,000$ for the erection of buildings at hospitals associated with the medical research scheme endowed by him in 1936 .

\section{Discovery of Teeth of Australopithecus}

AT the time of going to press, we have received a further communication from Dr. R. Broom, dated October 5, supplementing his letter under this title which appears on p. 681. He writes: "Since the above letter was written two weeks ago, four more teeth of Australopithecus have been discovered. Two are teeth of a very aged animal with the crowns almost completely worn off. One of these is a lower premolar, and the other a third left upper molar, but these are of little scientific value. The third tooth is a first upper incisor. Unfortunately, part of the crown is broken off and part of the root, but enough is preserved to show most of the structure. It is remarkably human. The width of the crown is about $10 \mathrm{~mm}$. and the whole length of the tooth probably about $32 \mathrm{~mm}$. The fourth tooth is the beautifully preserved crown of a right third upper molar. It agrees closely with the wisdom tooth of the type, but it is slightly more worn and has fewer corrugations. It probably belongs to the same individual as the third right lower molar tooth."

\section{Announcements}

THE Lord President of the Council has appointed Dr. G. M. B. Dobson, Lieut.-Colonel J. H. M. Greenly and Mr. S. K. Thornley to be members of the Advisory Council to the Committee of the Privy Council for Scientific and Industrial Research. Prof. A. Fowler, Sir Clement Hindley and Dr. T. Franklin Sibly have retired from the Council upon the completion of their terms of office.

THe first Radford Mather Lecture of the British Association will be given by the Right Hon. J. Ramsay MacDonald on Friday, October 22, at the Royal Institution, Albemarle Street, London, W.1, at 5 p.m. Mr. MacDonald will take as his subject "Science and the Community". The Norman Lockyer Lecture, on "Origins of Town Life in Britain : an Illustrated Review of Recent Evidence", will be given by Dr. R. E. Mortimer Wheeler in the Goldsmiths' Hall, Foster Lane, Cheapside, London, E.C.2, at 4 p.m. on Wednesday, November 24. Further information can be obtained from the Secretary, British Association, Burlington House, London, W.1.

The Iron and Steel Institute and the Institute of Metals have arranged to hold their 1938 autumn meetings in the United States, opening in New York jointly with the corresponding American Institutes on October 3. Technical sessions will be held on
October 3 and 4, and from then until October 21 visits will be made to various centres of technical interest in the United States. Further information can be obtained from the Secretary, Iron and Steel Institute, 28, Victoria Street, London, S.W.I.

THE Federation of Progressive Societies announces a series of fourteen lectures being given in the Conway Hall, Red Lion Square, W.C.1, at 8 p.m. Among the subjects and lecturers are: November 3 , eugenics and the class struggle, J. B. S. Haldane; November 10, sex and censorship, Norman Haire; January 5, 1938, the failure of intellectuals, Dora Russell ; February 2, the cultural basis for unity, John MacMurray. Particulars may be obtained from the hon. secretary of the Society, 4 Fitzroy Street, London, W.I.

THe following appointments and promotions have recently been made in the Colonial Service: B. de L. Inniss, agricultural superintendent, Gold Coast ; A. B. Lucy, agricultural officer, Malaya; A. F. Posnette, botanist, Agricultural Department, Gold Coast ; D. H. Welch, agricultural officer, Nigeria ; H. B. Burgess, assistant conservator of forests, Nigeria; J. H. Nelson Smith, assistant conservator of forests, British Honduras; P. R. Page, assistant conservator of forests, Nigeria ; C. I. Turner, veterinary officer, Malaya; G. K. Argles, manager, Fruit and Vegetable Development Scheme, Jamaica; E. G. A. Benson (assistant agricultural superintendent), agricultural superintendent, British Guiana; D. L. Blunt (director of agriculture, Cyprus), director of agriculture, Nyasaland; W. E. Freeman (late tobacco breeding officer, Mauritius), botanist, Agricultural Department, Nigeria ; E. F. S. Shepherd (botanist and mycologist, Agricultural Department, Mauritius), plant pathologist, Gold Coast ; J. P. Edwards (senior assistant conservator of forests), conservator of forests, Malaya; M. Crawford (Government veter. inary surgeon), deputy director (animal husbandry) and Government veterinary surgeon, Department of Agriculture, Ceylon; G. B. Simmins (veterinary research officer), senior veterinary research officer, Department of Agriculture and Fisheries, Palestine; M. A. Crane (chief draughtsman), research officer, Mechanical Engineering Department, Nigerian Railways; C. G. Fannin (district surveyor), chief surveyor, Kenya ; J. H. Haleblian (assistant chemist), chemist, Department of Antiquities, Palestine; A. S. McKinnon (assistant livestock officer, Veterinary Department, Tanganyika), agricultural officer, Veterinary and Agricultural Department, Somaliland; J. H. Nield (computer), district surveyor, Kenya; J. G. Reece (first assistant surveyor), deputy surveyor and deputy sub-intendant, Trinidad; H. Smith (assistant mechanical engineer, Public Works and Electricity Department, Zanzibar), inspector of machinery, Mines Department, Gold Coast; J. A. R. Stoyle (Government analyst, Mauritius), assistant Government analyst, Nigeria; W. G. W. Wilson (superintendent of workshops), chief mechanical engineer, Nigerian Railways. 